\title{
Effect of Investment Decisions, Capital Structure, Profit Management, Cash Flow of Corporate Social Resposibility Reporting, Financial Performance and Value of Manufacturing Companies Listed in Indonesia Stock Exchange
}

\author{
Prima Noermaning Attarie \\ University doctoral student, August 17, 1945, Surabaya, Indonesia \\ Tri Ratnawati \\ University lecturer, August 17, 1945 Surabaya, Indonesia \\ Srie Hartutie Moehaditoyo \\ University lecturer, August 17, 1945, Surabaya, Indonesia
}

\begin{abstract}
The manufacturing company is a company of processing raw materials into products sold into the market. Managers as managers of the company more knowing internal information and prospects of the company in the future than the owners (shareholders). As a Manager, the manager shall be obliged to provide a signal about the condition of the company to the owner. The given signal can be done through the disclosure of accounting information such as financial statements. Basic financial statements provide a lot of information required users to make economic decisions. This research was conducted using a sample of annual reports on the Indonesia stock exchange from the year 2014 to 2016, because the company was pretty much done regression techniques cross section by meeting some of the criteria which may be taken as sample. Sample from a population of 30 companies that meet the criteria of a sample with the limitations of Partial Least Square (PLS). Partial Least Squares is a factor indeterminacy analysis method which is powerful because it doesn't assume the data is to be with a certain scale and the measurement of the amount of the sample is small. Research results can be concluded that Investment decision, capital structure, free cash flow and earning management effect significantly to Corporate Social Responsibility (CSR) Disclosure on companies listed in Indonesia Stock Exchange (IDX). Investment decision and capital structure no effect on financial performance significantly to companies listed in IDX. Free cash flow and earning management effect significantly to financial performance in company listed in IDX. Investment decision do not affect significantly to the value of the firm at companies listed in IDX. Capital structure, free cash flow and earning management effect significantly to the value of companies listed in IDX. CSR Disclosure effect significantly to financial performance and value of the firm listed in IDX. CSR Disclosure and financial performance effect significantly to the value of the firm at companies listed in IDX.
\end{abstract}

Keywords: investment decisions, capital structure, earning management, free cash flow CSR Disclosure, financial performance and value of the firm.

\section{INTRODUCTION}

The number of manufacturing companies listed on the Indonesia Stock Exchange (IDX) encourages the occurrence of intense competition between manufacturers. The companies compete in the enterprise in order to improve the company's value can rise. Basic financial statements provide a lot of information required users to make economic decisions. Decision to be taken by the Manager of finance and the various activities are grouped into three main 
activities, namely activities using funds, acquiring funding and division of profits (Husnan, 2015:4).

Capital structure is a form of financial corporations i.e. proportion between capital which has sourced from the long term debt and private equity, which became the source of financing of an enterprise. Capital structure of a company consists of long term debt and shareholders equity, which the stockholder equity consists of preferred stock and common equity, and common equity itself is composed of common stock and retained earnings (Husnan, 2015:6).

Engineered financial statements as an attempt to put pressure on management. A concept that can be used to manage the management financial statements of the company in order to make the report look seen quality is known for its earnings management. This allows the company to perform manipulation of the income statement by creating in such a way in order to make the report more attractive look. Earning management can be done along don't stray from the standards of financial accounting (Husnan, 2015:65).

The users of the financial statements want to know information about the condition of the cash the company, to find out the capabilities of the company in generating cash. In general the parties interested parties more interested in information about the State of the free cash flow at the company's cash flow report. Free cash flow is cash flow available for distribution to the financier after the company invested in an additional fixed assets, an increase in working capital, which is required for maintain company growth (Husnan, 2015: 67).

Companies are required to publish annual reports with the aim to provide information to the user for a certain period. In addition, the user can rate the company information the company through non financial aspects IE CSR. Limited Liability Environment. In the PP is set regarding social and environmental responsibility aimed at realizing sustainable economic development in order to improve the quality of life and an environment that is beneficial to the local community and society in General as well as the company.

Referring to Statements of financial accounting standards No. 1 (revised 2012) paragraph 15, as an entity may also be present, separate from the financial statements, the report of the environment and reports added value, especially for industries where the factor the environment play an important role and for the industry that considers employees as a financial statement user groups play an important role. Additional reporting beyond the scope of the financial accounting standards. From this passage it can be concluded that Corporate social responsibility disclosure is an activity conducted by the company must make a report for the benefit of stakeholders.

Financial performance financial statements is owned by corporations/business entities are concerned and that is reflected in the information obtained on the balance sheet, the income statement, and cash flow statement (current reports cash) as well as other things contributing to as amplifier ratings. The parties concerned are able to assess the financial performance of the company among them by seeing the level of profitability, liquidity, solvency and will be used as the basis for decision making. (Fahmi, 2012:2).

Sartono (2012:478), the value of the firm is certain conditions that have been achieved by a company as an overview of the public confidence since the company was established up to the present moment. The increased value of the company is an achievement, which in accordance with the wishes of the owners, because with the increasing value of the welfare of the company, then the owner will also increase. 
Tsing (2012:478), the value of the firm is certain conditions that have been achieved by a company as an overview of the public confidence since the company was established up to the present moment. The increased value of the company is an achievement, which in accordance with the wishes of the owners, because with the increasing value of the welfare of the company, then the owner will also increase.

Based on the background that have been put forth, then researchers intrigued by the title Influence Investment Decisions, Capital Structure, Free Cash Flow, Earning Management Corporate Social Resposibility Reporting, Financial Performance and Value of manufacturing companies listed on the Indonesia Stock Exchange period in 2014 to 2016 with as many as 30 companies.

\section{Investment Decision}

\section{LITERATURE REVIEW AND HYPOTHESIS}

The investment is the placement of the amount at this time with the hope to gain an advantage in the future. The parties who perform investment activities referred investors. Investment is an expenditure-expenditure for the purchase of capital goods and production equipment for the purpose of replacing and especially adding to capital goods in an economy that will be used for the production of goods and services in the future (Halim, 2012: 4). The investment increases the well-being of investors (Investor's wealth). The goal of investing for the benefit of a more viable in the coming inflationary pressure, reduces, the drive to save on taxes.

\section{Capital Structure}

Gitman (2012:488), the definition of capital structure is as follows: capital superstructure is the mix of long term debt and equity maintained by the firm. Enterprise capital structure reflects the comparison between long-term debt and own capital used by the business. There are two kinds of capital tipe yaitu debt capital and own funds. Weston and Copeland (2010:221) that capital superstructure or the capitalization of the firm is the permanent financing represented by long-term debt, preferred stock and equity shareholder's. Siegel and Shim (2006:80) say capital super structure is the composition of ordinary shares, shares of preferen, and various classes like that, gains who were detained, and long-term debt retained by unity of effort to fund assets.

\section{Free Cash flow}

Cash flow is cash flow that is actually available to be distributed to all investors (shareholders and owners of debt) after the company put the entire investment on fixed assets, new products, and working capital are required to keep operations running (Brigham and Houston, 2010:65). The value of a company's operations will depend on the entire free cash flow expected in the future, which is defined as operating profit. after taxes minus the amount of investments in working capital and fixed assets needed to maintain the business. Free cash flow will reflect the cash actually available for distribution to the investors and managers to make the company become more valuable by increasing free cash flow.

\section{Earning Management}

Healy and Wahlen (2010: 6) earning management when managers use judgment in financial reporting and in structuring transaction to alter financial report to either mislead some stakeholder about underlying economic performance of the company, or to influence contractual outcome that depend on report accounting number. Based on this definition it can be concluded that the financial report is a medium of communication between the company's 
management and investors about the company's financial picture, therefore it is in the process of making the financial report has to be made with properly and honestly presented to users of the financial statements so that it can reduce the appearance of manipulation of accounting.

\section{Corporate Social Responsibility Disclosure}

Corporate Social Responsibility is a concept or action carried out by the company as the company's sense of responsibility towards the social as well as the environment in which the company is located. Disclosure in the financial statements can be grouped into two parts, namely the disclosure of which is compulsory, the disclosure of which is the provision that must be followed by every company that contains about things that It must be noted in the financial statements according to the applicable standards and disclosure which is voluntary that the disclosure is voluntary and social accountability reporting.

\section{Financial Performance}

Financial performance is the presentation of information concerning the assets, liabilities, income and expense, changes in equity and cash flow. This information is followed by the note, will help users predict future cash flows (Sutrisno, 2009:53).. Fahmi (2012:2) describes the financial performance was an analysis conducted to see the extent to which a company has done with the use of the financial implementation of the rules properly. Financial performance analysis is a process of assessment were critical towards the review of data, calculate, measure, menginterprestasi, and gives the solution to the financial company at a certain period. Financial ratios that are judged to be grouped into (Husnan, 2015:80): a ratio of profitability, asset management Ratios, liquidity ratio the ratio, the ratio of market value include the current ratio or current ratio (CR), Quick or acid test ratio and the ratio of growth.

\section{The Value of The Firm}

Maurice and Thomas (2002), Value of the firm is the price for which the firm can be sold, which equals the present value of future profits. For the company which issued the shares in the capital market, the price of shares traded on the Exchange, is an indicator of the value of the company. Maximise the company's market value is equal to maximise the price of the stock market. Measurement of the company's value in the research of Weston and Copeland (2004) in the ratio of company valuation consists of Price Earning Ratio (PER), Price to Book Value (PBV) and DPR.

\section{Hypothesis}

1. Investment decision effect significantly to CSR Disclosure on companies listed in IDX.

2. Capital structure influential significantly to CSR Disclosure on companies listed in IDX.

3. Free cash flow effect significantly to CSR Disclosure on companies listed in IDX.

4. Earning management effect significantly to CSR Disclosure on companies listed in IDX.

5. Investment decision effect on financial performance significantly to companies listed in IDX.

6. Capital structure effect on financial performance significantly to companies listed in IDX.

7. Cash flow effect significantly to financial performance in company listed in IDX.

8. Earning influential management significantly to financial performance in companies listed in IDX.

9. CSR disclosure effect significantly to financial performance in company listed in IDX.

10. Investment decision affect significantly to the value of the firm at companies listed in IDX.

11. Capital structure influential significantly to the value of companies listed in IDX.

12. Cash flow effect significantly to the to the value of the firm at company listed in IDX. 
13. Earning influential management significantly to the value of the firm at companies listed in IDX.

14. CSR disclosure of significant effect value of the firm at companies listed in IDX.

15. Financial performance effect significantly to the value of the firm at companies listed in IDX.

\section{Analysis Model}

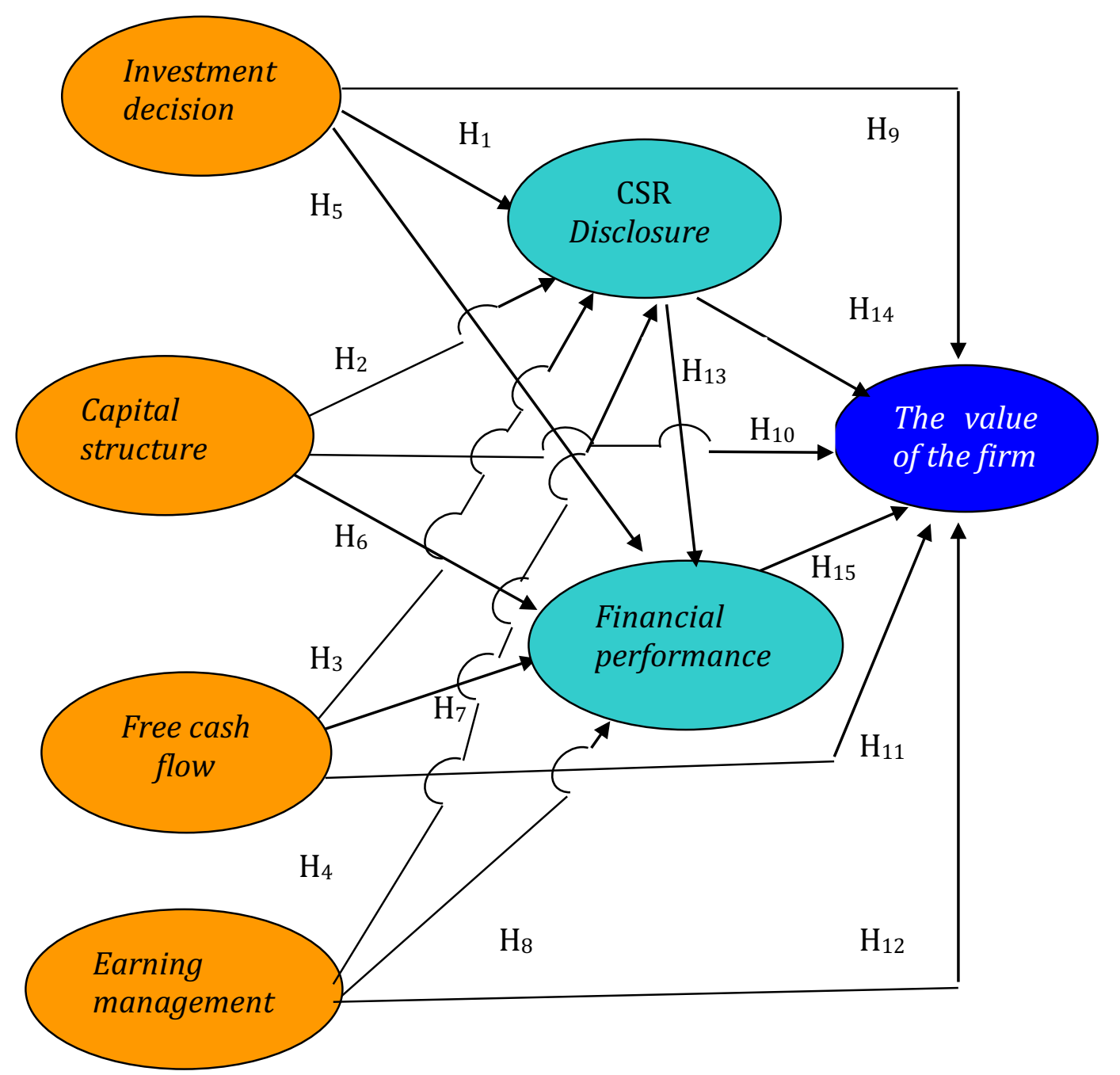

Figure 1. Analysis Model

\section{RESEARCH METHODS}

This research was conducted using a sample of annual reports on the Indonesia stock exchange from the year 2014 to 2016, because the company was pretty much done regression techniques cross section by meeting some of the criteria which may be taken as sample. Sample from a population of 30 companies that meet the criteria of a sample with the limitations of Partial Least Square (PLS). This research uses of data analysis in SEM (Structure Equational Modeling) using the Partial Least Square (PLS) (Ghozali, 2011).

\section{ANALYSIS AND DISCUSSION}

To prove the hypothesis that is by looking at the significance of the influence between variable by looking at the value of the parameters and the significance of coefficient $t$ statistic. On the things done PLS 2.0 by looking at Algorithm Boostrapping report, here's the result: 


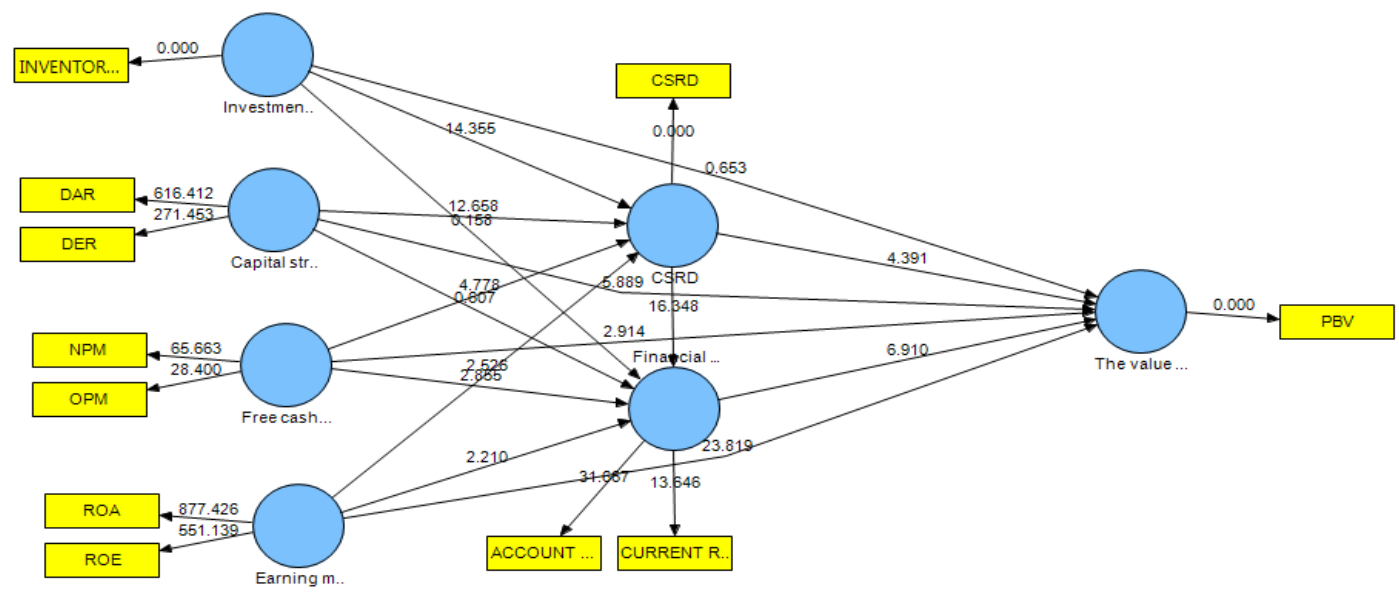

Fiture 2. Algorithm Boostrapping report

Tabel 1. Path Coefficients (Mean, STDEV, t-Values):

\begin{tabular}{|c|c|c|c|c|c|}
\hline & $\begin{array}{l}\text { Original } \\
\text { Sample (0) }\end{array}$ & $\begin{array}{l}\text { Sample Mean } \\
\text { (M) }\end{array}$ & $\begin{array}{l}\text { Standard Deviation } \\
\text { (STDEV) }\end{array}$ & $\begin{array}{l}\text { Standard Error } \\
\text { (STERR) }\end{array}$ & $\begin{array}{l}\text { t Statistics } \\
(\mid \text { O/STERR } \mid)\end{array}$ \\
\hline Investment decision -> CSRD & 0.303986 & -0.302605 & 0.021177 & 0.021177 & 14.354515 \\
\hline Capital structure -> CSRD & 0.265267 & 0.261866 & 0.020956 & 0.020956 & 12.658321 \\
\hline Free cash flow $->$ CSRD & 0.183820 & 0.175513 & 0.038471 & 0.038471 & 4.778197 \\
\hline Earning management -> CSRD & 0.051629 & -0.051198 & 0.020442 & 0.020442 & 2.525617 \\
\hline $\begin{array}{l}\text { Investment decision -> } \\
\text { Financial performance }\end{array}$ & 0.002277 & 0.004732 & 0.014453 & 0.014453 & 0.157553 \\
\hline $\begin{array}{l}\text { Capital structure ->Financial } \\
\text { performance }\end{array}$ & 0.006201 & 0.005449 & 0.010213 & 0.010213 & 0.607206 \\
\hline $\begin{array}{l}\text { Free cash flow -> Financial } \\
\text { performance }\end{array}$ & 0.035562 & 0.037683 & 0.012457 & 0.012457 & 2.854894 \\
\hline $\begin{array}{l}\text { Earning management -> } \\
\text { Financial performance }\end{array}$ & 0.033996 & 0.031935 & 0.015384 & 0.015384 & 2.209863 \\
\hline $\begin{array}{l}\text { Investment decision -> The } \\
\text { value of the firm }\end{array}$ & 0.008142 & 0.009977 & 0.012476 & 0.012476 & 0.652659 \\
\hline $\begin{array}{l}\text { Capital structure -> The value } \\
\text { of the firm }\end{array}$ & 0.144907 & 0.142270 & 0.024605 & 0.024605 & 5.889284 \\
\hline $\begin{array}{l}\text { Free cash flow }->\text { The value of } \\
\text { the firm }\end{array}$ & 0.080051 & 0.079058 & 0.027467 & 0.027467 & 2.914473 \\
\hline $\begin{array}{l}\text { Earning management -> The } \\
\text { value of the firm }\end{array}$ & 0.685802 & 0.686003 & 0.028793 & 0.028793 & 23.818729 \\
\hline CSRD -> Financial performance & 0.299803 & 0.300336 & 0.018339 & 0.018339 & 16.347794 \\
\hline CSRD -> The value of the firm & 0.065814 & 0.063823 & 0.014988 & 0.014988 & 4.391100 \\
\hline $\begin{array}{l}\text { Financial performance -> The } \\
\text { value of the firm }\end{array}$ & 0.145005 & 0.149950 & 0.020984 & 0.020984 & 6.910182 \\
\hline
\end{tabular}

Path Coefficient the level of significance of the relationships between variables in the research and the results are as follows

$\mathbf{H}_{1}$ : Investment decision significant influential towards CSR Disclosure on manufacturing companies registered in IDX. Influence Investment decision to CSR Disclosure is significant with t-statistic of $14.354515>1.96$. The value of the original sample estimate of 0.303986 which indicates that the direction of the relationship between Investment decision to CSR Disclosure is positive or both ways. Then it can be inferred that the hypothesis $1\left(\mathrm{H}_{1}\right)$ accepted.

$\mathbf{H}_{2}$ : Capital structure influential significantly to CSR Disclosure on companies listed in IDX. 
Attarie, P. N., Ratnawati, T., \& Moehaditoyo, S. H. (2018). Effect of Investment Decisions, Capital Structure, Profit Management, Cash Flow of Corporate Social Resposibility Reporting, Financial Performance and Value of Manufacturing Companies Listed in Indonesia Stock Exchange. Archives of Business Research, 6(5), 158-167.

Influence capital structure towards CSR Disclosure was significant with t-statistics 12.658321 $>$ amounted to 1.96. The value of the original sample estimate of 0.265267 which indicates that the direction of the relationship between capital structure towards CSR Disclosure is positive or one direction. Then it can be inferred that the hypothesis $2\left(\mathrm{H}_{2}\right)$ accepted.

$\mathbf{H}_{3}$ : Free cash flow effect significantly to CSR Disclosure on companies listed in IDX. free cash flow against the influence of CSR Disclosure was significant with t-statistics of $4.778197>1.96$. The value of the original sample estimate of 0.183820 which indicates that the direction of the relationship between free cash flow towards CSR Disclosure is positive or one direction. Then it can be inferred that the hypothesis $3\left(\mathrm{H}_{3}\right)$ accepted.

$\mathbf{H}_{4}$ : Earning management effect significantly to CSR Disclosure on companies listed in IDX. Influence earning management towards CSR Disclosure was significant with t-statistics $2.525617>$ amounted to 1.96 . The value of the original sample estimate of 0.051629 which indicates that the relationship between the direction of earning management towards CSR Disclosure is positive or one direction. Then it can be inferred that the hypothesis $4\left(\mathrm{H}_{4}\right)$ accepted.

$\mathbf{H}_{5}=$ Investment decision has no effect on financial performance significantly to companies listed in IDX. Influence investment decisions toward financial perfomance is significant with tstatistic of $0.157553<1.96$. The value of the original sample estimate of 0.002277 which indicates that the direction of the relationship between the investment decision against financial performance is negative. Then it can be inferred that the hypothesis $5\left(\mathrm{H}_{5}\right)$ rejected.

$\mathbf{H}_{6}=$ Capital structure has no effect on financial performance significantly to companies listed in IDX. The influence of capital structure towards the IDX financial perfomance is significant with t-statistic of $0.607206>1.96$. The value of the original sample estimate of 0.006201 which indicates that the direction of the relationship between capital structure towards the financial performance was negative. Then it can be inferred that the hypothesis $6\left(\mathrm{H}_{6}\right)$ rejected.

$\mathbf{H}_{7}=$ Free cash flow effect significantly to financial performance in company registered in IDX. Influence of free cash flow against the financial perfomance is significant with t-statistic of $2.854894>1.96$. The value of the original sample estimate of 0.035562 which indicates that the direction of the relationship between free cash flow against the financial performance was positive or one direction. Then it can be inferred that the hypothesis of $7\left(\mathrm{H}_{7}\right)$ is received.

$\mathbf{H}_{\mathbf{8}}=$ Earning influential management significantly to financial performance in company registered in IDX. Influence earning management against financial perfomance is significant with t-statistic of $2.209863>1.96$. The value of the original sample estimate of 0.033996 which indicates that the relationship between the direction of earning management against the financial performance was positive or one direction. Then it can be inferred that the hypothesis $8\left(\mathrm{H}_{8}\right)$ is received.

$\mathbf{H}_{\mathbf{9}}=$ CSR disclosure effect significantly to financial performance in company registered in IDX. Influence CSR disclosure against the financial perfomance is significant with t-statistics of $16.347794>1.96$. The value of the original sample estimate of 0.299803 which indicates that the direction of the relationship between CSR disclosure against the financial performance was positive or one direction. Then it can be inferred that the hypothesis of $9\left(\mathrm{H}_{9}\right)$ accepted. 
$\mathbf{H}_{10}=$ Investment decision do not affect significantly to the value of the firm at companies listed in IDX. Influence investment decisions against the value of the firm is significant with t-statistic of $0.157553>1.96$. The value of the original sample estimate of 0.002277 which indicates that the relationship between the investment direction of deciosion against the value of the firm is negative. Then it can be inferred that the hypothetical $10\left(\mathrm{H}_{10}\right)$ was rejected.

$\mathbf{H}_{11}=$ Capital structure influential significantly to the value of the firm at companies listed in IDX. Influence capital structure against the value of the firm is significant with t-statistic of $0.157553>1.96$. The value of the original sample estimate of 0.002277 which indicates that the direction of the relationship between capital structure against the value of the firm is positive or one direction. Then it can be inferred that the hypothesis of $11\left(\mathrm{H}_{11}\right)$ accepted.

$\mathbf{H}_{\mathbf{1 2}}=$ free cash flow effect significantly to the value of the firm at companies listed in IDX. Influence of free cash flow against the value of the firm is significant with t-statistic of $5.889284>1.96$. The value of the original sample estimate of 0.144907 which indicates that the direction of the relationship between free cash flow against the value of the firm is positive or one direction. Then it can be inferred that the hypothesis $12\left(\mathrm{H}_{12}\right)$ are accepted.

$\mathbf{H}_{\mathbf{1 3}}=$ earning influential management significantly to the value of the firm at companies listed in IDX. Influence earning management against the value of the firm is significant with t-statistic of $2.209863>1.96$. The value of the original sample estimate of 0.033996 which indicates that the relationship between the direction of earning management against the value of the firm is positive or one direction. Then it can be inferred a hypothesis $13\left(\mathrm{H}_{13}\right)$ accepted.

$\mathbf{H}_{\mathbf{1 4}}=$ CSR disclosure of significant effect against the value of the firm at companies listed in IDX. Influence CSR disclosure against the value of the firm is significant with t-statistics of 4.391100 $>1.96$. The value of the original sample estimate of 0.065814 which indicates that the direction of the relationship between CSR disclosure against the value of the firm is positive or one direction. Then it can be inferred that the hypothesis $14\left(\mathrm{H}_{14}\right)$ accepted.

$\mathbf{H}_{15}=$ financial performance effect significantly to the value of the firm at companies listed in IDX. Influence financial performance against the value of the firm is significant with t-statistic of $6.910182>1.96$. The value of the original sample estimate of 0.145005 which indicates that the direction of the relationship between financial performance against the value of the firm is positive or one direction. Then it can be inferred that the hypothesis of $15\left(\mathrm{H}_{15}\right)$ are accepted.

\section{SUMMARY}

1. Investment decision effect significantly to CSR Disclosure on companies listed in IDX.

2. Capital structure influential significantly to CSR Disclosure on companies listed in IDX.

3. Free cash flow effect significantly to CSR Disclosure on companies listed in IDX.

4. Earning management effect significantly to CSR Disclosure on companies listed in IDX.

5. Investment decision has no effect on financial performance significantly to companies listed in IDX.

6. Capital structure has no effect on financial performance significantly to companies listed in IDX.

7. Cash flow effect significantly to financial performance in company listed in IDX.

8. Earning influential management significantly to financial performance in companies listed in IDX.

9. CSR disclosure effect significantly to financial performance in company listed in IDX.

10. Investment decision do not affect significantly to the value of the firm at companies listed in IDX. 
Attarie, P. N., Ratnawati, T., \& Moehaditoyo, S. H. (2018). Effect of Investment Decisions, Capital Structure, Profit Management, Cash Flow of Corporate Social Resposibility Reporting, Financial Performance and Value of Manufacturing Companies Listed in Indonesia Stock Exchange. Archives of Business Research, 6(5), 158-167.

11. Capital structure influential significantly to the value of companies listed in IDX.

12. Cash flow effect significantly to the to the value of the firm at company listed in IDX.

13. Earning influential management significantly to the value of the firm at companies listed in IDX.

14. CSR disclosure of significant effect value of the firm at companies listed in IDX.

15. Financial performance effect significantly to the value of the firm at companies listed in IDX.

\section{LIMITATIONS}

1. For the company, the management companies need to improve the performance of the company's cash flow is mainly an investment decision, capital structure and the management of profit and free on the company, in order to assist investors in making investment decisions on the company's corporate objectives, i.e. increasing the value of the company.

2. For investors choose companies with high profit, so that investors can obtain a dividend refund rate is high.

3. For further research on the author suggests the use of variables could potentially affect the company's growth and financial reporting

\section{BIBLIOGRAPHY}

Gitman, Lawrence J dan Chad J. Zutter. 2012. Principles of Managerial Finance. 13 ${ }^{\text {th }}$ Edition.Global Edition: Pearson Education Limited.

Healy and Wahlen. 2010. A Review Of The Earnings Management Literature. And Its Implications For Standart Setting.

Brigham and Houston. 2010. Financial Management basics book 1. (11th Edition). Salemba Jakarta: Four.

Copeland, Thomas E. And J. Fred Weston. 2002. Financial Management Edition. Ninth, Fahmi, Jakarta.

Irham. 2012. The analysis of the financial statements. 2nd print. Bandung: Alfabeta.

Husnan, Suad. 2015. Dasar-Dasar Teori Portofolio dan Analisis Sekuritas. (Edisi 5). Yogyakarta.

Halim, Abdul. 2012. Analisis Laporan Keuangan. Edisi. Ketiga. Cetakan Pertama. Penerbit UPP Sekolah Tinggi Ilmu Manajemen. YKPN. Yogyakarta.

Husnan, Suad. 2015. The basics of Portfolio Theory and the analysis of securities. (5th Edition). Yogyakarta.

Halim, Abdul. 2012. The analysis of the financial statements. Editions. The third. First Printing. Publisher UPP High School Management Science. YKPN. Yogyakarta.

Maurice, S. Charles and Thomas, Christopher R. 2002. Managerial Economics, Edisi. Ketujuh. New York: McGrawHill

Sutrisno. 2009, Manajemen Keuangan Teori, Konsep dan Aplikasi, Edisi Pertama, Cetakan. Ketujuh, Penerbit Ekonisia, Yogyakarta

Husnan, Suad. 2015. The basics of Portfolio Theory and the analysis of securities. (5th Edition). Yogyakarta. Sutrisno. 2009, financial management Theories, concepts and applications, first edition, prints. Seventh, The Publisher Of Ekonisia, Yogyakarta

Weston, J. Feed and Thomas E. Copeland. 2010. Financial management. Jakarta

Husnan, Suad. 2015. The basics of Portfolio Theory and the analysis of securities. (5th Edition). Yogyakarta.

Halim, Abdul. 2012. The analysis of the financial statements. Editions. The third. First Printing. Publisher UPP High School Management Science. YKPN. Yogyakarta.

Bond Accountant Indonesia. 2012. The financial accounting standards. Jakarta.

Maurice, Charles s. and Thomas, Christopher r. 2002. Production Management, Economics, Editions. The seventh. New York: McGraw-Hill. 
Siegel, Joel, G and Shim, Jae k. 2006. Dictionary Of Accounting Terms, Prints The Third. Jakarta.

Sutrisno. 2009, financial management Theories, concepts and applications, first edition, prints. Seventh, the Publisher of Ekonisia, Yogyakarta.

Weston, J. Feeds and Thomas, E. Copeland. 2010. Financial management. Jakarta 